\title{
Response to comment on: Semi-automatic assessment of skin capillary density: Proof of principle and validation
}

Citation for published version (APA):

Muris, D. M. J., Gronenschild, E. H. B. M., Schram, M. T., Karaca, U., Stehouwer, C. D. A., \& Houben, A. J. H. M. (2014). Response to comment on: Semi-automatic assessment of skin capillary density: Proof of principle and validation. Microvascular Research, 94, 7-8. https://doi.org/10.1016/j.mvr.2014.04.006

Document status and date:

Published: 01/07/2014

DOI:

10.1016/j.mvr.2014.04.006

Document Version:

Publisher's PDF, also known as Version of record

Document license:

Taverne

Please check the document version of this publication:

- A submitted manuscript is the version of the article upon submission and before peer-review. There can be important differences between the submitted version and the official published version of record.

People interested in the research are advised to contact the author for the final version of the publication, or visit the DOI to the publisher's website.

- The final author version and the galley proof are versions of the publication after peer review.

- The final published version features the final layout of the paper including the volume, issue and page numbers.

Link to publication

\footnotetext{
General rights rights.

- You may freely distribute the URL identifying the publication in the public portal. please follow below link for the End User Agreement:

www.umlib.nl/taverne-license

Take down policy

If you believe that this document breaches copyright please contact us at:

repository@maastrichtuniversity.nl

providing details and we will investigate your claim.
}

Copyright and moral rights for the publications made accessible in the public portal are retained by the authors and/or other copyright owners and it is a condition of accessing publications that users recognise and abide by the legal requirements associated with these

- Users may download and print one copy of any publication from the public portal for the purpose of private study or research.

- You may not further distribute the material or use it for any profit-making activity or commercial gain

If the publication is distributed under the terms of Article 25fa of the Dutch Copyright Act, indicated by the "Taverne" license above, 


\section{Letter to the Editor}

\section{Response to comment on: Semi-automatic assessment of skin capillary density: Proof of principle and validation}

We thank Dr. Neubauer-Geryk and co-workers for their comments concerning our recent article on the description of a semi-automatic technique for the assessment of skin capillary density (CapiAna) (Gronenschild et al., 2013). In their letter, three important issues were raised (Neubauer-Geryk et al.,).

First, Neubauer et al. mention that measuring changes in skin capillary density only partly addresses the phenomenon of skin microvascular reactivity. We fully agree with this issue. Nevertheless, the variables we used, i.e., hyperemic (functional) capillary recruitment and venous congestion, are thought to reflect functional and structural capillary density, respectively (Antonios et al., 1999; Serne et al., 2001). Indeed, skin capillaries in the resting state are thought to work on a 'rota system' (i.e., some are temporarily perfused, whereas others are temporarily shut down), and capillaries intermittently perfused in the resting state seem to be an important functional reserve that can be recruited during post-occlusive reactive hyperemia (PORH) (Antonios et al., 1999; Serne et al., 2001). In addition, venous congestion increases venous back pressure, which allows passive trapping of red blood cells in non-perfused and intermittently perfused capillaries, thereby enhancing the visualization of capillaries filled with red blood cells (i.e., allows visualization of the maximal number of skin capillaries) (Antonios et al., 1999; Serne et al., 2001). Thus, regardless of the issue that skin capillary density only partly addresses the phenomenon of skin microvascular reactivity, ample evidence is available indicating that hyperemic (functional) capillary recruitment and venous congestion are functional and structural, and therefore physiologically relevant, measures of the skin microcirculation, respectively.

Second, Neubauer et al. point out that the capillary densities as measured with CapiAna and the manual counting procedure were statistically different. We found, however, a borderline significant $(P=0.06)$ difference in baseline capillary density derived with CapiAna as compared to the manual counting procedure $\left(4.5[-0.3 ; 9.3]\right.$ capillaries $\left./ \mathrm{mm}^{2}\right)$. In addition, the capillary densities during hyperemic (functional) capillary recruitment and venous congestion did not differ significantly between CapiAna and the manual counting procedure. Next, analyzing agreement with Bland-Altman analysis is the most appropriate way to compare two methods (Bland and Altman, 1986). With a Bland-Altman analysis, we showed a mean difference of 2.0 capillaries $/ \mathrm{mm}^{2}$ between the methods with acceptable limits of agreement $(-13.5 ; 18.4$ capillaries $/ \mathrm{mm}^{2}$ ). More importantly, we found no evidence for systematic errors between CapiAna and the manual counting procedure over the range of capillary densities studied. Thus, these results indicate that CapiAna can be used for a wide range of capillary densities.

Third, Neubauer et al. raise questions about the duration of ischemia and, additionally, about differences in skin capillary density between a recovery time of 5 min (used in our study) as compared to the "typical" $10 \mathrm{~min}$ (Antonios et al., 1999). For the assessment of arterial occlusion, a miniature cuff was inflated to suprasystolic levels for $4 \mathrm{~min}$, as described in materials and methods section (subsection "skin capillaroscopy"; page 193). The commonly used occlusion of 4 min (Jonk et al., 2010; Serne et al., 2001) is expected to cause vasodilatation through both the mechanism of myogenic vasodilatation and metabolic vasodilatory stimuli (Johnson et al., 1976). For logistic reasons (i.e., the use of an extensive phenotyping approach of the Maastricht Study (Schram et al., 2014)), we used a recovery time of 5 min between PORH and venous congestion. Unfortunately, we do not have data on possible differences in skin capillary density between recovery times of 5 min as compared to $10 \mathrm{~min}$. Nevertheless, in line with previous literature (Antonios et al., 1999; Jonk et al., 2010; Serne et al., 2001), we clearly demonstrated that the maximal number of capillaries observed with venous congestion (95.2 \pm 24.4 capillaries $/ \mathrm{mm}^{2}$ ) exceeds that observed with PORH $\left(87.4 \pm 21.9\right.$ capillaries $\left./ \mathrm{mm}^{2}\right)$. Thus, these observations support the conclusion that the recovery time between conditions used in our study was sufficient.

In conclusion, assessment of skin microvascular reactivity by capillaroscopy, using different stimuli, may be an important diagnostic tool for the evaluation of skin microcirculation (Jonk et al., 2010; Neubauer-Geryk et al., 2013, 2014; Serne et al., 2001). In addition, CapiAna is in agreement with the manual counting procedure, has a better reproducibility as compared to the manual counting procedure and is time-saving. As a result, CapiAna facilitates the assessment of functional and structural skin capillary density, and thus the investigation of the skin microcirculation in health and disease.

\section{References}

Antonios, T.F., Rattray, F.E. Singer, D.R, et al, 1999. Maximization of skin capillaries during intravital video-microscopy in essential hypertension: comparison between venous congestion, reactive hyperaemia and core heat load tests. Clin. Sci. (Lond.) 97, 523-528.

Bland, J.M., Altman, D.G., 1986. Statistical methods for assessing agreement between two methods of clinical measurement. Lancet 1, 307-310.

Gronenschild, E.H., Muris, D.M., Schram, M.T., et al., 2013. Semi-automatic assessment of skin capillary density: proof of principle and validation. Microvasc. Res. 90, 192-198.

Johnson, P.C., Burton, K.S., Henrich, H., et al., 1976. Effect of occlusion duration on reactive hyperemia in sartorius muscle capillaries. Am. J. Physiol. 230, 715-719.

Jonk, A.M., Houben, A.J., Schaper, N.C., et al., 2010. Angiotensin II enhances insulinstimulated whole-body glucose disposal but impairs insulin-induced capillary recruitment in healthy volunteers. J. Clin. Endocrinol. Metab. 95, 3901-3908.

Neubauer-Geryk, J., Kozera, G.M., Nyka, W.M., et al., 2014. Comment to article: semiautomatic assessment of skin capillary density: proof of principle and validation. Microvasc. Res. http://dx.doi.org/10.1016/j.mvr.2014.02.010.

Neubauer-Geryk, J., Kozera, G.M., Wolnik, B., et al., 2013. Decreased reactivity of skin microcirculation in response to L-arginine in later-onset type 1 diabetes. Diabetes Care 36, 950-956.

Schram, M.T., Sep, S.J., Kallen van der, C.J., et al., 2014. The Maastricht Study: an extensive phenotyping study on determinants of type 2 diabetes, its complications and its comorbidities. Eur. J. Epidemiol. http://dx.doi.org/10.1007/s10654-014-9889-0.

Serne, E.H., Gans, R.O., ter Maaten, J.C., et al., 2001. Impaired skin capillary recruitment in essential hypertension is caused by both functional and structural capillary rarefaction. Hypertension 38, 238-242. 
D.M.J. Muris

Department of Internal Medicine, Cardiovascular Research Institute Maastricht (CARIM), Maastricht University Medical Centre (MUMC), Maastricht, The Netherlands E-mail address: d.muris@maastrichtuniversity.nl.

E.H.B.M. Gronenschild Department of Psychiatry and Neuropsychology, School for Mental Health and Neuroscience (MeHNs), Maastricht University Medical Centre (MUMC), Maastricht, The Netherlands E-mail address: ed.gronenschild@maastrichtuniversity.nl.
Maastricht, The Netherlands

*Corresponding author at: Maastricht University Medical Centre, Department of Internal Medicine, P.O. Box 5800, 6202 AZ, Maastricht,

The Netherlands.

E-mail addresses: m.schram@maastrichtuniversity.nl (M.T. Schram), u.karaca@maastrichtuniversity.nl (U. Karaca), cda.stehouwer@mumc.nl (C.D.A. Stehouwer), b.houben@maastrichtuniversity.nl (A.J.H.M. Houben).

M.T. Schram

Ü. Karaça

C.D.A. Stehouwer

A.J.H.M. Houben*

Department of Internal Medicine, Cardiovascular Research Institute Maastricht (CARIM), Maastricht University Medical Centre (MUMC), 